\title{
Intracellular mGluR5 Can Mediate Synaptic Plasticity in the Hippocampus
}

\author{
Carolyn A. Purgert, ${ }^{1}$ Yukitoshi Izumi, ${ }^{2}$ Yuh-Jiin I. Jong, ${ }^{1}$ Vikas Kumar, ${ }^{1}$ Charles F. Zorumski, ${ }^{1,2}$ and Karen L. $0^{\text {'Malley }}{ }^{1}$ \\ ${ }^{1}$ Department of Anatomy and Neurobiology, Washington University School of Medicine, St. Louis, Missouri 63110, and ${ }^{2}$ Department of Psychiatry and \\ Taylor Family Institute for Innovative Psychiatric Research, Washington University School of Medicine, St. Louis, Missouri 63110
}

Metabotropic glutamate receptor 5 (mGluR5) is widely expressed throughout the CNS and participates in regulating neuronal function and synaptic transmission. Recent work in the striatum led to the groundbreaking discovery that intracellular mGluR 5 activation drives unique signaling pathways, including upregulation of ERK1/2, Elk-1 (Jong et al., 2009) and Arc (Kumar et al., 2012). To determine whether mGluR5 signals from intracellular membranes of other cell types, such as excitatory pyramidal neurons in the hippocampus, we used dissociated rat CA1 hippocampal cultures and slice preparations to localize and characterize endogenous receptors. As in the striatum, CA1 neurons exhibited an abundance of mGluR5 both on the cell surface and intracellular membranes, including the endoplasmic reticulum and the nucleus where it colocalized with the sodium-dependent excitatory amino acid transporter, EAAT3. Inhibition of EAAT3 or sodium-free buffer conditions prevented accumulations of radiolabeled agonist. Using a pharmacological approach to isolate different pools of mGluR5, both intracellular and cell surface receptors induced oscillatory $\mathrm{Ca}^{2+}$ responses in dissociated CA1 neurons; however, only intracellular mGluR5 activation triggered sustained high amplitude $\mathrm{Ca}^{2+}$ rises in dendrites. Consistent with the notion that mGluR5 can signal from intracellular membranes, uncaging glutamate on a CA1 dendrite led to a local Ca ${ }^{2+}$ rise, even in the presence of ionotropic and cell surface metabotropic receptor inhibitors. Finally, activation of intracellular mGluR5 alone mediated both electrically induced and chemically induced long-term depression, but not long-term potentiation, in acute hippocampal slices. These data suggest a physiologically relevant and important role for intracellular mGluR5 in hippocampal synaptic plasticity.

Key words: calcium; hippocampus; intracellular; LTD; mGluR5

\section{Introduction}

G-protein-coupled receptors (GPCRs) are thought of as simple on-off switches in which extracellular ligands activate cell surface receptors, resulting in G-protein activation and second messenger induction. The on-off switch has now given way to multifaceted, higher-order structures of homomers or heteromers within which allosteric mechanisms can alter ligand binding, G-protein coupling, receptor internalization, trafficking, and G-protein-independent signaling (Denis et al., 2012; Reiter et al., 2012). With the discovery that GPCRs can trigger signaling cascades from intracellular membranes (O’Malley et al., 2003; Jong et al., 2005, 2009; Kumar et al., 2008; Bkaily et al., 2012; He-

Received Aug. 12, 2013; revised Jan. 24, 2014; accepted Feb. 19, 2014.

Author contributions: C.A.P., C.F.Z., and K.L.O. designed research; C.A.P., Y.I., Y.-J.I.., and V.K. performed research; C.A.P., Y.I., and Y.-J.I.J. analyzed data; C.A.P. and K.L.O. wrote the paper.

This work was supported by National Institutes of Health Grant 1F30MH091998-01 to C.A.P. and Grants AA017413, MH077791, and GM47969 to Y.I. and C.F.Z., FRAXA to C.A.P., V.K., and K.L.O., the Simons Foundation to C.A.P., I.J., V.K., and K.L.O., the MCDonnell Center for Cellular and Molecular Neurobiology to C.A.P., I.J., V.K., and K.L.O., and the Bantly Foundation to Y.I. and C.F.Z. We thank Steve Harmon, Kazuko Izumi, and Dennis Oakley for technical assistance.

C.F.Z. serves on the Scientific Advisory Board of Sage Therapeutics. The remaining authors declare no competing financial interests.

Correspondence should be addressed to Dr. Karen L. O'Malley, Anatomy \& Neurobiology, Washington University School of Medicine, 660 South Euclid Avenue, St. Louis, M0 63110. E-mail: omalleyk@pcg.wustl.edu.

DOI:10.1523/JNEUROSCI.3451-13.2014

Copyright $\odot 2014$ the authors $\quad 0270-6474 / 14 / 344589-10 \$ 15.00 / 0$ wavitharana and Wedegaertner, 2012), referred to here as "location bias," GPCR functionality has become even more complex.

The metabotropic glutamate receptor 5 (mGluR5) exemplifies this more complex view of GPCR signaling. Not only can mGluR5 dimerize with itself (Romano et al., 1996) and other GPCRs (Hubert et al., 2001), it can be regulated by both positive and negative allosteric modulators that can potentiate or inhibit the endogenous ligand, glutamate, respectively. mGluR5 also exhibits pronounced location bias in that $60-90 \%$ of mGluR5 is associated with intracellular membranes (Hubert et al., 2001; López-Bendito et al., 2002; O’Malley et al., 2003). In the striatum, previous studies from this laboratory show that endogenous intracellular mGluR5 is functional, that it is activated by its neurotransmitter entering neurons via sodium or chloridedependent transporters/exchangers (Jong et al., 2005; Kumar et al., 2008), and that intracellular mGluR5 specifically triggers a cascade of molecular events starting with phosphorylation of ERK1/2 and Elk-1 (Jong et al., 2009), followed by increased expression of synaptic plasticity genes $c$-fos, egr-1, and Arc (Kumar et al., 2012). Thus, activation of intracellular mGluR5 initiates a cascade of events underlying synaptic plasticity.

Given that mGluR5 is involved in many disorders, including fragile X syndrome/autism spectrum disorder, schizophrenia, anxiety, addiction, levodopa-induced dyskinesias, gastroesophageal reflux disease, chronic pain, and epilepsy (Catania et al., 2007; Cleva and Olive, 2011; Blandini and Armentero, 2012; Gray 
et al., 2012), drugs that modulate its function may be extremely useful in treating these disorders. Because it might be possible to target drugs from one pool of receptors to another, it is critical to understand how mGluR5 signals from both the cell surface as well as intracellular locales. Although genetic manipulations have failed to cleanly isolate mGluR5 from one membrane versus another (unpublished results), pharmacological isolation is achieved via specific impermeable, nontransported drugs, including the antagonist LY53 and the agonist DHPG, as well as transported or permeable drugs, such as the agonists, Quis and CHPG, and the antagonist, MPEP (Jong et al., 2005, 2009). Here we show, for the first time, that intracellular mGluR5 plays a critical role in a specific form of hippocampal synaptic plasticity.

\section{Materials and Methods}

Hippocampal cell culture. Primary hippocampal cultures were prepared and maintained as described previously with some modifications (Jong et al., 2005). Briefly, coverslips placed in 12-well plates were coated with poly-D-lysine for 3-16 $\mathrm{h}$ and then washed three times with sterile water. After drying, the coverslips were coated with $80 \mu \mathrm{l}$ of Neurobasal A (Invitrogen) and prewarmed at $37^{\circ} \mathrm{C}$. Dissociated hippocampal cultures were prepared using postnatal day 1 (P1) or $\mathrm{P} 2$ rat pups. After decapitation, brains were immediately removed and placed in cold sterile PBS. Hippocampi were carefully removed under a dissecting microscope, and the CA1 region was enriched by removing the dentate gyrus and CA3 regions along the inner curve of the hippocampal structure. The CA1enriched hippocampi were diced into $1 \mathrm{~mm}$ pieces and incubated at $37^{\circ} \mathrm{C}$ $5 \% \mathrm{CO}_{2} / 95 \% \mathrm{O}_{2}$ for $15 \mathrm{~min}$ in a papain solution consisting of $0.2 \mathrm{mg} / \mathrm{ml}$ BSA, $1 \mathrm{mg} / \mathrm{ml}$ papain, and $1 \mathrm{mg} / \mathrm{ml}$ DNaseI in Neurobasal A supplemented with glutamine, B-27, and penicillin/streptomycin $\left(\mathrm{NBA}^{+}\right)$. The solution was mixed every $5 \mathrm{~min}$ during incubation. After incubation, the supernatant was removed and the tissue was washed twice with $3 \mathrm{ml}$ of warm $\mathrm{NBA}^{+}$. After removing the supernatant again, $5 \mathrm{ml}$ of $\mathrm{NBA}^{+}$was used to triturate the tissue $\sim 5$ times through a $5 \mathrm{ml}$ pipette and then 8 times through a $200 \mu$ l pipette tip. Cells were pelleted by centrifuging at $700 \mathrm{rpm}$ for 5-10 min. The supernatant was removed, and the cells were resuspended in $1 \mathrm{ml}$ of $\mathrm{NBA}^{+}$and counted on a hemocytometer using Trypan blue to assess cell death. The cells were plated at a density of 40,000 cells/ $10 \mathrm{~mm}$ coverslip. Cells were allowed to adhere for $1 \mathrm{~h}$, and then $1.5 \mathrm{ml}$ of $\mathrm{NBA}^{+}$was added to each well. Cells were fed on DIV4-6 and on DIV11-12 by removing half of the media and replacing it with fresh $\mathrm{NBA}^{+}$

Immunocytochemistry. Hippocampal cultures were fixed, blocked, and incubated as described previously (Jong et al., 2005). Primary antibodies include rabbit polyclonal anti-mGluR5 (Millipore, 1:150), mouse GFAP (Cell Signaling Technology, 1:300), mouse monoclonal anti-laminB2 (Invitrogen, 1:100), and mouse monoclonal anti-EAAT3 (Millipore, 1:500). Secondary antibodies include goat anti-rabbit or anti-mouse Cy3 (Jackson ImmunoResearch Laboratories, 1:300), and goat anti-rabbit or mouse Alexa-488 (Invitrogen, 1:300).

Subcellular fractionation. Subcellular fractionation was performed as described previously (O’Malley et al., 2003; Jong et al., 2007). Specifically, postnatal days $1,5,10,15$, and adult rat hippocampi were dissected and minced on ice with a razor blade followed by resuspension in 20 volumes of hypotonic buffer A containing $2.0 \mathrm{~mm} \mathrm{MgCl} 2,25 \mathrm{~mm} \mathrm{KCl}, 10 \mathrm{~mm}$ HEPES, pH 7.5, and protease inhibitors (Complete Tablets; Roche Applied Science). Cells swelled for $10 \mathrm{~min}$ on ice followed by homogenization using 15 strokes with a "B" pestle in a Wheaton glass homogenizer. The homogenate was filtered through 3 layers of sterile gauze, centrifuged at $1000 \times \mathrm{g}$ for $10 \mathrm{~min}$, and the nuclear pellet was resuspended in $3 \mathrm{ml}$ of buffer $\mathrm{N}$ ( $0.25 \mathrm{M}$ sucrose in buffer $\mathrm{A})$. Resuspended nuclei were layered over $2 \mathrm{ml}$ of $1.1 \mathrm{M}$ sucrose in buffer $\mathrm{A}$ and then recentrifuged at $1000 \times \mathrm{g}$. After repeating the previous step twice, the final nuclear pellet comprised the nuclear fraction, whereas the supernatant from the first pellet was concurrently further fractionated by centrifugation at $35,000 \times \mathrm{g}$ for $40 \mathrm{~min}$. This second supernatant represented soluble, cytoplasmic proteins, whereas the high-speed pellet contained plasma membrane proteins. The nuclear and plasma membrane fractions were suspended in buffer $(150 \mathrm{~mm} \mathrm{NaCl}, 1 \mathrm{~mm}$ EDTA, $0.1 \%$ SDS, $1 \%$ Nonidet

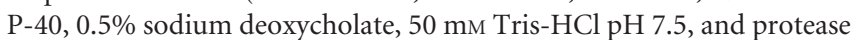
inhibitors) and subjected to SDS-PAGE (see below). Nuclei from P1-P5 hippocampi were also isolated using subcellular fractionation, fixed to glass coverslips, and immunostained as described previously (Jong et al., 2005).

Western blot analysis. Protein sample concentrations were assessed with the Bradford assay (Bio-Rad). Samples were separated via SDSPAGE, blotted, and probed with antibodies as described previously (Jong et al., 2007). Primary antibodies include rabbit polyclonal anti-mGluR5 (Millipore, 1:750), monoclonal anti-Lamin B2 (Invitrogen, 1:2000), polyclonal anti-pan-cadherin (Cell Signaling Technology, 1:2000), and monoclonal anti- $\beta$-actin (Sigma, 1:1000). Secondary antibodies included HRP conjugated with goat anti-rabbit IgG (Cell Signaling Technology, 1:2000) or anti-mouse IgG (Sigma, 1:2000). Signal was detected using enhanced chemiluminescence (GE Healthcare), and densitometric analyses of mGluR5 proteins were performed by using the Storm 860 Imager (GE Healthcare) or ChemiDoc MP System (Bio-Rad) with associated software.

Uptake experiments. ${ }^{3} \mathrm{H}$-Labeled agonist uptake experiments were performed using radiolabeled (L)- $(+)$ - $\alpha$-amino-3,5-dioxo-1,2,4-oxadiazolidine-2-propanoic acid (quisqualate; abbreviated Quis) $(22.0 \mathrm{Ci} /$ $\mathrm{mmol}$ ) obtained from PerkinElmer and radiolabeled L-glutamate (43.0 $\mathrm{Ci} / \mathrm{mmol}$ ) obtained from GE Healthcare. Experiments were completed as described previously (Jong et al., 2005). Specifically, unlabeled drug was added to radiolabeled agonists $\left(3.25 \mu \mathrm{Ci} / \mathrm{ml}\left[{ }^{3} \mathrm{H}\right]\right.$ Quis or $43.08 \mu \mathrm{Ci} / \mathrm{ml} \mathrm{L}^{-}\left[{ }^{3} \mathrm{H}\right]$ glutamate) to achieve a total Quis or glutamate concentration of $1 \mu \mathrm{M}$. Primary hippocampal cultures were prepared using PDL-coated 48-well plates with a density of 40,000 cells/well. Cells were washed three times in the appropriate buffer (total buffer, containing $\mathrm{Na}^{+}$and $\mathrm{Cl}^{-}: 137 \mathrm{~mm} \mathrm{NaCl}, 5.1 \mathrm{~mm} \mathrm{KCl}, 0.77 \mathrm{~mm} \mathrm{KH}_{2} \mathrm{PO}_{4}, 0.71 \mathrm{~mm}$ $\mathrm{MgSO}_{4} .7 \mathrm{H}_{2} \mathrm{O}, 1.1 \mathrm{~mm} \mathrm{CaCl}_{2}, 10 \mathrm{~mm}$ D-glucose, $10 \mathrm{~mm}$ HEPES; chloridefree buffer: $130 \mathrm{~mm}$ Na gluconate, $5 \mathrm{~mm}$ K gluconate, $0.77 \mathrm{~mm} \mathrm{K \textrm {H } _ { 2 }} \mathrm{PO}_{4}$, $0.71 \mathrm{~mm} \mathrm{MgSO}_{4} .7 \mathrm{H}_{2} \mathrm{O}, 1.1 \mathrm{~mm}$ Ca gluconate, $10 \mathrm{~mm}$ D-glucose, $10 \mathrm{~mm}$ HEPES; sodium-free buffer: $137.5 \mathrm{~mm}$ choline $\mathrm{Cl}, 5.36 \mathrm{~mm} \mathrm{KCl}, 0.77 \mathrm{~mm}$ $\mathrm{MgSO}_{4} \cdot 7 \mathrm{H}_{2} \mathrm{O}, 1.1 \mathrm{~mm} \mathrm{CaCl}_{2}$ ) and then incubated at $37^{\circ} \mathrm{C}$ in the presence or absence of various competitors/inhibitors for $15 \mathrm{~min}$ before adding labeled agonist. Drugs included (S)-3,5-dihydroxyphenylglycine (DHPG), (RS)-2-chloro-5-hydroxyphenylglycine (CHPG), L-cystine, and DL-threo- $\beta$-benzyloxyaspartic acid (TBOA), all from Tocris Bioscience. Uptake was terminated after $15 \mathrm{~min}$, and samples were rapidly rinsed three times with ice-cold PBS. Cells were solubilized in $150 \mu \mathrm{l}$ of $1 \%$ Triton X-100/PBS and then analyzed by liquid scintillation. Statistical significance was assessed using two-tailed, unpaired sample $t$ tests with Bonferroni corrections for multiple testing.

$\mathrm{Ca}^{2+}$ imaging. $\mathrm{Ca}^{2+}$ imaging was performed using DIV14-18 hippocampal cultures loaded with Oregon Green BAPTA-AM as described previously (Jong et al., 2009). Images were analyzed using MetaMorph software as described previously (Jong et al., 2009). Agonists DHPG, CHPG, and Quis and inhibitors ( \pm )-4(4-aminophenyl)-1,2-dihydro-1-methyl-2-propylcarbamoyl-6, 7-methylene-dioxyphthalazine (SYM2206), 7-(hydroxyimino)cyclopropa[b]chromen-1a-carboxylate ethyl ester (CPCCOEt), and MPEP were obtained from Tocris Bioscience. Impermeable, nontransported antagonist 3-[(1S)-1-amino-1-carboxy-2-(9H-thioxanthen-9-yl)ethyl] cyclobutane-1-carboxylic acid (LY393053; abbreviated LY53) was obtained from Eli Lilly.

Caged glutamate experiments. DIV11-15 hippocampal cultures were loaded with Oregon Green BAPTA-AM as described previously (Jong et al., 2005). Cells were kept at $37^{\circ} \mathrm{C}$ and imaged on an Olympus FV1000 confocal microscope. Where indicated, the following inhibitors were used at the indicated concentration: D-([minua])-2-amino-5-phosphonopentanoic acid (APV, NMDA receptor antagonist, $100 \mu \mathrm{M}$, Tocris Bioscience); 6-cyano-7-nitroquinoxaline-2,3-dione (CNQX, AMPA receptor antagonist, $20 \mu \mathrm{M}$, Tocris Bioscience); (2S)-2-amino-2-[(1S,2S)2-carboxycycloprop-1-yl]-3-(xanth-9-yl) propanoic acid (LY341495, Group 2/3 mGluR antagonist, $100 \mathrm{~nm}$, Tocris Bioscience); CPCCOEt (mGluR1 antagonist, $20 \mu \mathrm{M}$ ), and LY53 (nontransported mGluR5 antag- 
onist, $20 \mu \mathrm{M})$. 4-Methoxy-7-nitroindolinyl-caged-L-glutamate (MNIglu, Tocris Bioscience) was added at a concentration of $500 \mu \mathrm{M}$. Experiments were performed by applying a $405 \mathrm{~nm}$ laser for $300 \mathrm{~ms}$ to small regions of interest (ROI) on neurites after waiting for $30 \mathrm{~s}$ to establish baseline $\mathrm{Ca}^{2+}$ levels. $\mathrm{Ca}^{2+}$ responses in the ROI and control areas were analyzed using MetaMorph software.

Electrophysiology. Hippocampal slices were prepared from P 28-32 albino rats using standard methods (Izumi and Zorumski, 2012). Rats were anesthetized with isoflurane and decapitated. Dissected hippocampi were placed in ice-cold ACSF containing the following (in $\mathrm{mm}$ ): $124 \mathrm{NaCl}, 5 \mathrm{KCl}, 2 \mathrm{MgSO}_{4}, 2 \mathrm{CaCl}_{2}, 1.25 \mathrm{NaH}_{2} \mathrm{PO}_{4}, 22 \mathrm{NaHCO}_{3}, 10$ glucose, bubbled with $95 \% \mathrm{O}_{2}-5 \% \mathrm{CO}_{2}$ at $4-6^{\circ} \mathrm{C}$, and cut into $450 \mu \mathrm{m}$ slices using a rotary slicer. Acutely prepared slices were placed in an incubation chamber containing gassed ACSF for at least $1 \mathrm{~h}$ at $30^{\circ} \mathrm{C}$ before further experimentation. Based on numerous prior experiments, we have found this approach to provide reliable data for synaptic plasticity experiments.

At the time of study, hippocampal slices were transferred individually to a submersion-recording chamber. Experiments were done at $30^{\circ} \mathrm{C}$ with continuous ACSF perfusion at $2 \mathrm{ml} / \mathrm{min}$. Extracellular recordings were obtained from the apical dendritic layer (stratum radiatum) of the CA1 region for analysis of EPSPs using electrodes filled with $2 \mathrm{M} \mathrm{NaCl}$ (5-10 $\mathrm{M} \Omega$ resistance). EPSPs were evoked with $0.1 \mathrm{~ms}$ constant current pulses through a bipolar stimulating electrode in the Schaffer collateral pathway. A control input-output curve was obtained to determine stimulus intensities for subsequent studies. Responses were monitored by applying single stimuli to the Schaffer collateral pathway every 1 min or 5 min at half-maximal intensity. After establishing a stable baseline for at least $10 \mathrm{~min}$, long-term depression (LTD) was induced by applying a 1 $\mathrm{Hz}$ stimulus to the Schaffer collateral pathway for $15 \mathrm{~min}$. Long-term potentiation (LTP) was induced by a single $100 \mathrm{~Hz} \times 1 \mathrm{~s}$ tetanus using the same intensity stimulus. Input-output curves were repeated $60 \mathrm{~min}$ after tetanic stimulation. All chemicals were purchased from Sigma or Tocris Bioscience.

Data were collected and analyzed using PClamp software (Molecular Devices). Data in the text are expressed as mean \pm SEM 60 min following low-frequency stimulation (LFS) or high-frequency stimulation (HFS), and are normalized with respect to initial baseline recordings (taken as $100 \%$ ). A two-tailed Student's $t$ test was used for comparisons between groups. In cases of non-normally distributed data, the nonparametric Mann-Whitney Rank Sum Test was used. Statistical comparisons were based on input-output curves at baseline and $60 \mathrm{~min}$ after tetanic or $1 \mathrm{~Hz}$ stimulation, with $p<0.05$ considered significant and were done using commercial software (SigmaStat, Systat Software).

\section{Results}

mGluR5 is expressed on intracellular membranes in the hippocampus where it can be activated via sodium-dependent transport of Quis or glutamate

CA1-enriched hippocampal cultures expressed mGluR5 on the cell surface, along dendrites, and within the cell body, where dense staining around the nucleus colocalized with Lamin B2, a nuclear envelope marker (Fig. 1A,B). No detectable mGluR5 staining was seen on cocultured astrocytes, marked with GFAP (Fig. 1A). As in the striatum (Jong et al., 2005), antibodies directed against EAAT3 revealed that, in hippocampal neurons, EAAT3 is highly expressed on cell bodies and processes as well as intracellularly (Fig. $1 B$, middle, right panels). Acutely isolated hippocampal nuclei also exhibited mGluR5 staining, which colocalized with Lamin B2 (Fig. 1C). Subcellular fractionation of hippocampal tissue collected between newborn (P1) and adult ages revealed strong mGluR5 staining in both nuclear and plasma membrane fractions as delineated by the membrane specific markers, Lamin B2 and pan-cadherin (Fig. $1 D-G$ ). Levels of nuclear receptors in P5 through adult samples were increased over P1 levels, peaking at P10 and P15 (Fig. $1 E, G$ ), similar to previous findings in the striatum (Jong et al., 2005).
To directly test whether sodium or chloride-dependent processes were involved in Quis or glutamate uptake in CA1 cells, cultures were treated with radiolabeled ligand in the presence and absence of transport or exchange inhibitors. Glutamate blocked $\sim 70 \%$ of Quis transport, whereas DHPG did not compete with the uptake of either radiolabeled agonist (Fig. $1 \mathrm{H}, \mathrm{I}$ ). In contrast to the striatum, no role for the cystine glutamate exchanger $(\mathrm{xCT})$ was seen in $\mathrm{CA} 1$ cultures; rather, a sodium-dependent, TBOA-inhibited process accounted for $80-90 \%$ of ${ }^{3} \mathrm{H}$-glutamate uptake and $\sim 50 \%$ of ${ }^{3} \mathrm{H}$-Quis uptake (Fig. $1 H, I$ ). The process responsible for the remaining Quis uptake is unclear at present. The vesicular glutamate transporter (VGLUT) inhibitor Evans blue did not affect Quis uptake, nor did addition of succinate (data not shown), indicating that neither VGLUTs nor succinate transporters are involved in Quis transport. Therefore, in both striatal (Jong et al., 2005) and CA1 cultures, EAAT-mediated activity is primarily responsible for intracellular glutamate uptake.

Also in agreement with data from the striatum (Jong et al., 2009), glutamate binding assays showed no significant differences in receptor binding between DHPG and Quis to either plasma membrane or intracellular membrane sources $(\mathrm{DH}-$ $\mathrm{PG}_{\text {plasma membrane }} \mathrm{IC}_{50}=0.92 \pm 0.29 \mu \mathrm{M} ; \mathrm{DHPG}_{\text {nuclei }} \mathrm{IC}_{50}=$ $2.96 \pm 1.00 \mu \mathrm{M}$ vs Quis plasma membrane $\mathrm{IC}_{50}=0.76 \pm 0.12 \mu \mathrm{M}$; Quis $_{\text {nuclei }} \quad \mathrm{IC}_{50} \stackrel{\text { a }}{=} \quad 3.08 \quad \pm \quad 0.89 \quad \mu \mathrm{M}$; $p=0.0674$ for $\mathrm{DHPG}_{\text {plasma membrane }} \mathrm{vs} \mathrm{DHPG}_{\text {nuclei }} ; p=0.0671$ for Quis plasma membrane $_{\text {vs Quis }}$ nuclei $p=0.310$ for DHPG $_{\text {plasma membrane }}$

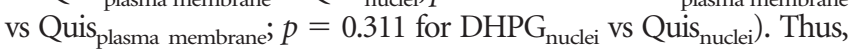
differences in binding properties between DHPG and Quis cannot account for differences in activation of cell surface versus intracellular mGluR5.

\section{Differential $\mathrm{Ca}^{2+}$ responses are seen in dendrites after intracellular, but not cell surface, mGluR5 activation}

In CA1-enriched cultures, the impermeable, nontransported agonist, DHPG, induced pronounced cytoplasmic $\mathrm{Ca}^{2+}$ oscillations, which could be blocked by the permeable antagonist, MPEP (Fig. 2A). Akin to striatal neurons (Jong et al., 2005), the impermeable/ nontransported antagonist LY53, by itself, did not induce intracellular $\mathrm{Ca}^{2+}$ changes (Fig. $2 B$ ); instead, it completely blocked DHPGmediated $\mathrm{Ca}^{2+}$ responses (Fig. $2 B$ ). These data confirm and extend our finding that DHPG selectively activates plasma membrane receptors that are susceptible to inhibition by the LY53 antagonist. In contrast, Quis induced cytoplasmic $\mathrm{Ca}^{2+}$ oscillations, even in the presence of LY53 (Fig. 2B). These oscillations were inhibited when MPEP was added (Fig. 2B). Similarly, the mGluR5-specific agonist CHPG triggered $\mathrm{Ca}^{2+}$ oscillations, even in the presence of LY53, which were similarly blocked by MPEP (Fig. 2C). Oscillatory $\mathrm{Ca}^{2+}$ responses were also observed in dendrites after activation of cell surface mGluR5 (Fig. 2D) or intracellular mGluR5 (Fig. 2E,F). Dendrites, identified based on morphological criteria and MAP2 staining (data not shown), showed no agonist-mediated differences in oscillation frequency versus CA1 somal responses (Fig. $2 G$ ). Similarly, no agonistmediated differences in amplitude were measured in CA1 soma, whereas significantly increased amplitudes attributable to intracellular mGluR5 were observed in dendrites (Fig. 2H). Increased amplitude was associated with sustained $\mathrm{Ca}^{2+}$ responses (Fig. $2 E, F$ ), such as those commonly seen in striatal neurons (Jong et al., 2005). Forty to $80 \%$ of CA1 dendrites exhibited highamplitude, sustained $\mathrm{Ca}^{2+}$ responses measured $50 \mu \mathrm{m}$ from the cell body after intracellular mGluR5 activation (Fig. 2I). These data support the concept that mGluR5 can couple to unique effector mechanisms depending upon the following: (1) the cell type in which it is expressed (inhibitory medium spiny neurons 
A
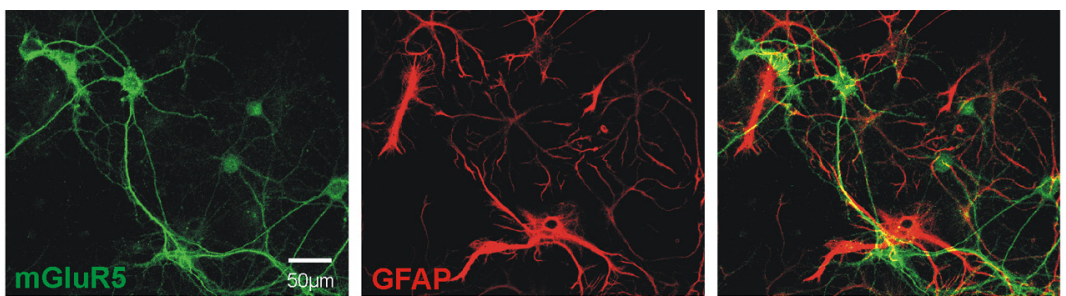

B
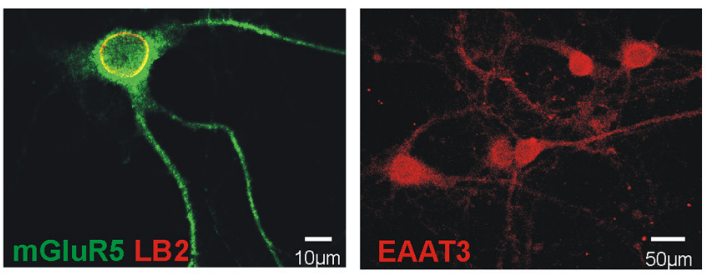

C
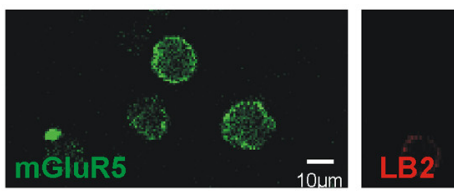

PM NUC

mGluR5

Lamin B2

Pan-Cad

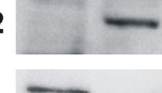

F

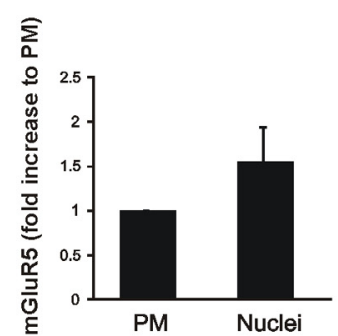

H

${ }^{3} \mathrm{H}$-Quisqualate Uptake

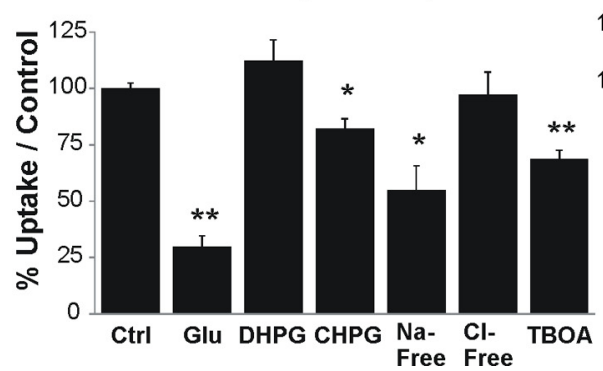

125

$\mathbf{G}=$

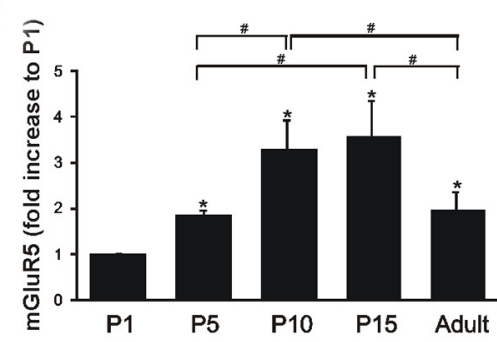

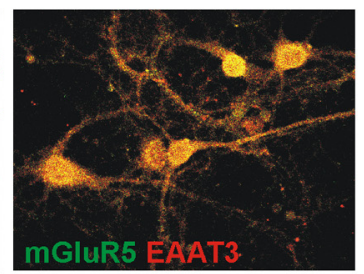

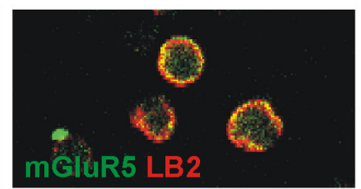

E

mGluR5

Lamin B2

$\beta$-actin

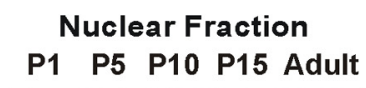

P1 P5 P10 P15 Adult

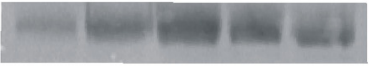

\section{.}

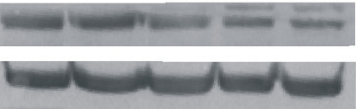

Figure 1. mGluR5 present on intracellular hippocampal membranes can be activated by EAAT3-dependent transport of glutamate or Quis. A, Immunostaining for mGluR5 (green, left), GFAP (red, middle), and an overlay image showing that mGluR5 is not expressed in GFAP-positive cells (astrocytes) in DIV14 rat CA1-enriched hippocampal cultures. B, Left, Confocal images of mGluR5positive hippocampal neuron costained for the nuclear membrane marker Lamin B2 showing the receptor present in the cytoplasm, neurites, and as a densely stained ring corresponding to the nuclear membrane. Middle, CA1-enriched hippocampal cultures also express EAAT3, which is coexpressed with $\mathrm{mGluR5}$ (right). C, Isolated adult rat hippocampal nuclei coexpress mGluR5 and Lamin B2. D, Subcellular fractionation of adult mouse hippocampi shows that mGluR5 can be detected in fractions containing either plasma (PM) or nuclear membranes (NUC). A total of $30 \mu \mathrm{g}$ of protein from each fraction was separated on reducing SDS gels and transferred to PVDF membranes. The same blot was cut and probed with antibodies against $m G$ luR5, the inner nuclear marker, Lamin B2, and the plasma membrane marker, Pan-cadherin. $\boldsymbol{E}$, Top, P1, P5, P10, P15, and adult rat isolated nuclei were electrophoretically separated as in $\boldsymbol{D}$ and immunoblotted in an identical fashion. $\boldsymbol{F}$, Quantification of $\mathrm{mGluR5}$ expression in mouse PM and nuclear fractions shown in $\boldsymbol{D} ; n=3$. G, Quantification of rat hippocampal mGluR5 expression across different ages as shown in $\boldsymbol{E}$. ${ }^{*} p<0.05$, compared with P1 levels. ${ }^{\#} p<0.05 . n=3 . \boldsymbol{H},\left[{ }^{3} \mathrm{H}\right]$ Quis uptake

in striatum vs excitatory pyramidal CA1 neurons); or (2) whether the receptor is localized to the dendrite or the soma.

Intracellular mGluR5 can mediate local $\mathrm{Ca}^{2+}$ changes in dendrites

Although we have primarily characterized intracellular mGluR5 expressed on nuclear membranes in the striatum, ultrastructure studies have also shown large numbers of mGluR5 gold particles on endoplasmic reticulum (ER) membranes (O'Malley et al., 2003). Moreover, many earlier ultrastructural studies of various brain regions from the rat, mouse, and monkey have shown large amounts of intracellular mGluR5 in dendrites (e.g., Mitrano and Smith, 2007) (see Fig. 4D), at the edge of asymmetric postsynaptic specializations and extrasynaptically along the plasma membrane (Lujan et al., 1996; Hanson and Smith, 1999; Hubert et al., 2001; Kuwajima et al., 2004; Mitrano et al., 2008, 2010). To address the question as to whether mGluR5 expressed on dendritic ER or endosomal membranes can mediate local $\mathrm{Ca}^{2+}$ rises, intracellular receptors were pharmacologically isolated by blocking cell surface mGluR5 with LY53 as well as other potential glutamate targets, such as the ionotropic receptors (NMDARs, AMPARs, kainate receptors), mGluR1, and Groups 2 and 3 mGluRs. In addition to inhibitors, extracellular buffer also contained MNI-glutamate, which was uncaged using laser-induced photolysis onto dendrites at least $20 \mu \mathrm{m}$ away from the cell body (Fig. 3). Only the region of the dendrite juxtaposed to the uncaging spot exhibited a change in fluorescence whereas proximal regions revealed no such fluorescent changes (Fig. 3), and this $\mathrm{Ca}^{2+}$ response was blocked in the presence of MPEP. These data indicate that activation of dendritic, intracellular mGluR5 leads to in situ $\mathrm{Ca}^{2+}$ changes with neither input to nor output from the cell soma.

mGluR5 knock-out mice do not exhibit mGluR5-dependent synaptic plasticity We used mGluR5-deficient animals to determine the specificity of agonistmediated $\mathrm{Ca}^{2+}$ responses in hippocampal

$\leftarrow$

in hippocampal cultures in the presence of $100 \mu \mathrm{m}$ glutamate, $100 \mu \mathrm{M}$ DHPG, 50-100 $\mu \mathrm{m}$ TBOA, or buffer conditions modified as indicated. Bars indicate experimental mean $\pm \mathrm{SE}$. ${ }^{*} p<0.01,{ }^{* *} p<0.001(n=15$ glu; $n=6$ DHPG; $n=9$ Na-free and (I-free conditions; $n=15$ TBOA). I, $\left[{ }^{3} \mathrm{H}\right]$ Glutamate uptake in hippocampal cultures in the presence of 100 $\mu \mathrm{m}$ DHPG, $20 \mu \mathrm{m}$ LY53, $400 \mu \mathrm{m}$ L-cystine (L-Cys), $100 \mu \mathrm{m}$ TBOA, or buffer conditions modified as indicated. Bars indicate the mean of 3 experiments \pm SE. ${ }^{*} p<0.01$. 


\section{Soma}

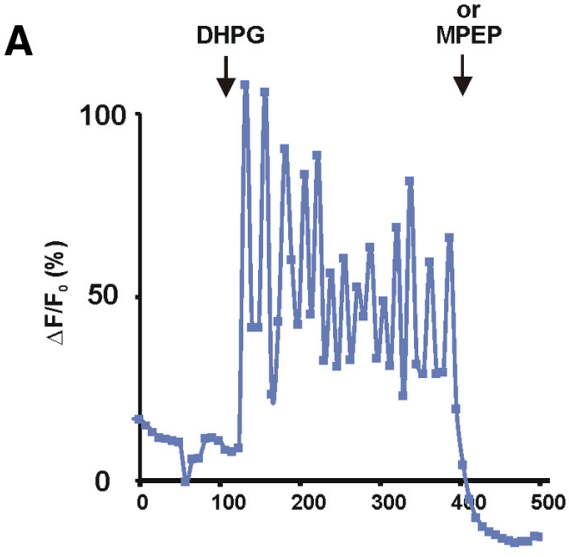

\section{Dendrites}

D
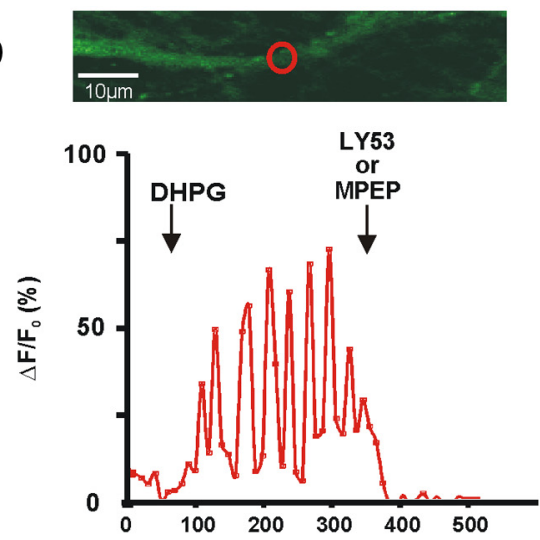

B

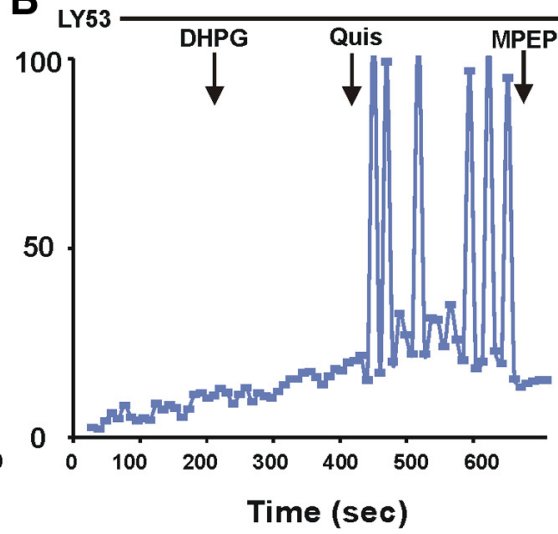

C

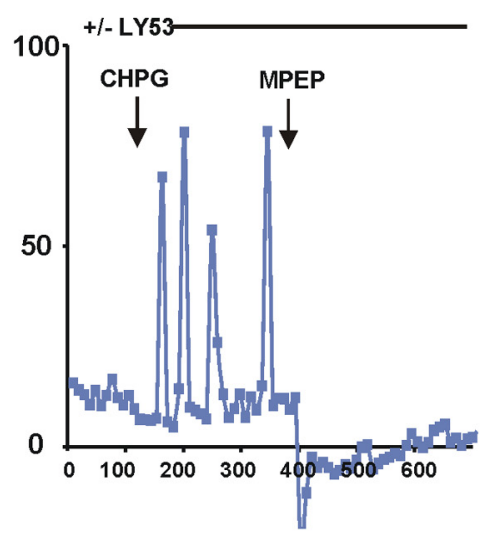

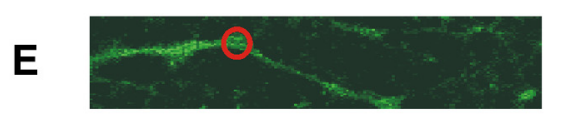
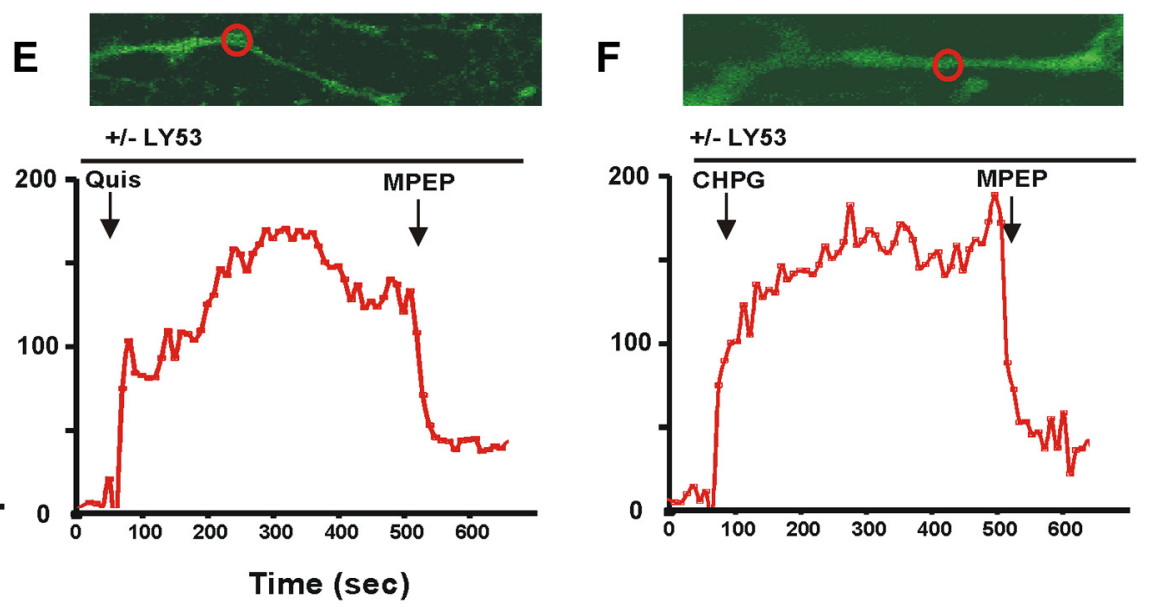

\section{Frequency \& Amplitude}
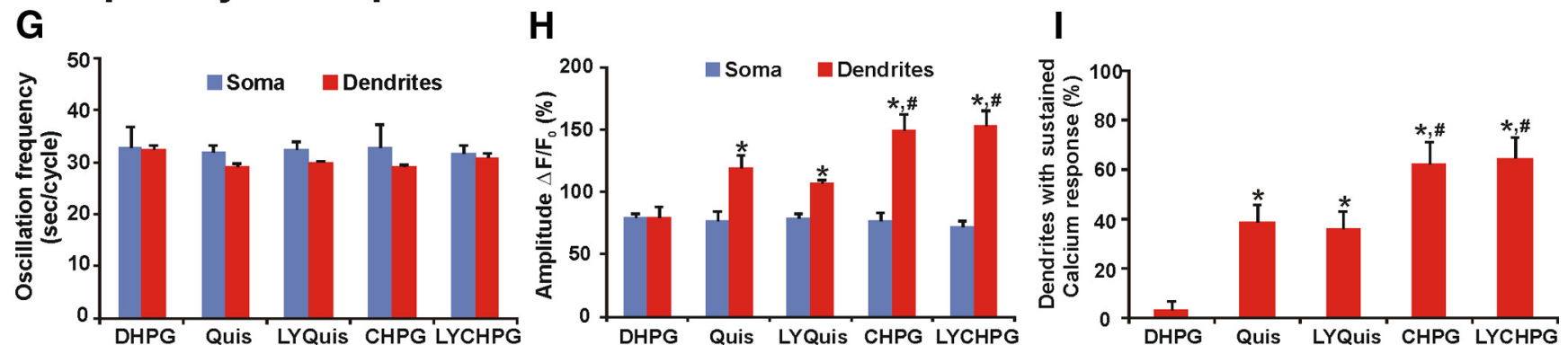

Figure 2. Both cell surface and intracellular mGluR5 produce $\mathrm{Ca}^{2+}$ oscillations in cell bodies, whereas only intracellular receptors induce sustained $\mathrm{Ca}^{2+}$ responses in dendrites. $\boldsymbol{A}-\boldsymbol{F}$, Representative traces of $\mathrm{Ca}^{2+}$ responses in dissociated CA1 neurons represented as the fractional change in fluorescence relative to the basal level. Neurons were treated with the indicated agonists and antagonists by bath application at the time indicated by the black arrows. The black bar represents pretreatment of cultures with the nontransported mGluR5 antagonist LY53. The AMPA receptor blocker SYM2206 $(20 \mu \mathrm{m})$ and the mGluR1 blocker CPCCOEt $(20 \mu \mathrm{M})$ were included in all experiments. Data were acquired at $9.59 \mathrm{~s} / \mathrm{scan}$. DHPG was used at $10-100 \mu \mathrm{M}, \mathrm{LY} 53$ at $20 \mu \mathrm{m}$, Quis at $20 \mu \mathrm{m}$, and MPEP at 1-10 $\mu \mathrm{m}$. A, Cytoplasmic $\mathrm{Ca}^{2+}$ oscillations induced by 10 or $100 \mu \mathrm{m}$ DHPG are inhibited by application of MPEP. B, Pretreatment with the nontransported mGluR5 antagonist LY53 blocks DHPG but not Quis-induced $\mathrm{Ca}^{2+}$ oscillations. C, The transported agonist CHPG is also able to produce $\mathrm{Ca}^{2+}$ oscillations in the presence of $L$ Y 53 . D-F, DHPG induces $\mathrm{Ca}{ }^{2+}$ oscillations in dendrites $\sim 50 \mu \mathrm{m}$ from the cell body (D), whereas dendritic intracellular mGluR5 (defined by Quis or CHPG treatment in the presence of LY53) produce more pronounced and sustained $\mathrm{Ca}^{2+}$ responses $(\boldsymbol{E}, \boldsymbol{F}) . \mathbf{G}-\boldsymbol{I}$, Compiled data of $\Delta F / F_{o}(\%)$ for frequency of oscillations $(\boldsymbol{G})$ in soma (blue bar) or dendrites (red bar), for amplitude $(\boldsymbol{H})$ and for sustained responses $(\boldsymbol{I})$ from $n>60$ neurons or $n>30$ neurites from three independent experiments. ${ }^{*} p<0.05$, compared with baseline $\mathrm{Ca}^{2+}$ responses. ${ }^{*} p<0.01$, compared with baseline $\mathrm{Ca}^{2+}$ responses. Cells with at least 3 oscillations of at least $25 \%$ change in fluorescence were included in calculations for oscillatory frequency.

neurons and mGluR5-mediated LTP and LTD. Hippocampal cultures prepared from knock-out mGluR5 P1 mouse pups failed to display oscillatory $\mathrm{Ca}^{2+}$ responses after application of Quis, whereas wild-type littermate animals displayed oscillations sim- ilar to those seen in rat hippocampal cultures (Fig. 4A,B). In addition, electrical LTP and LTD paradigms failed to induce persistent synaptic strength changes in P30 hippocampal slice preparations from mGluR5 knock-out mice versus wild-type 
A

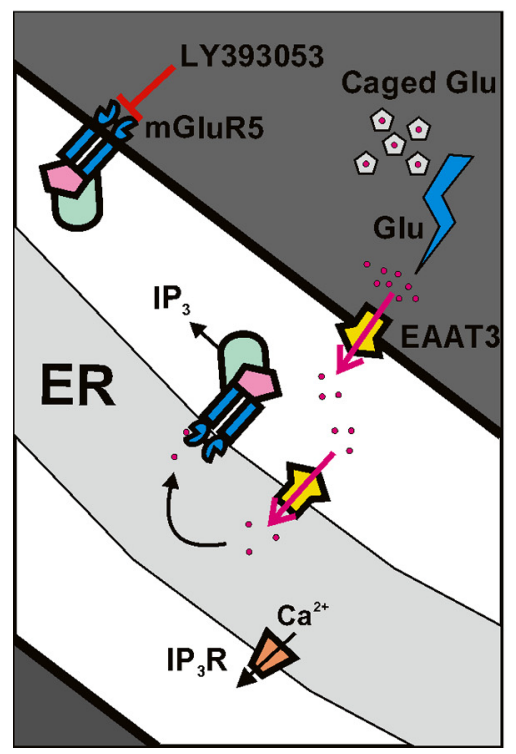

B

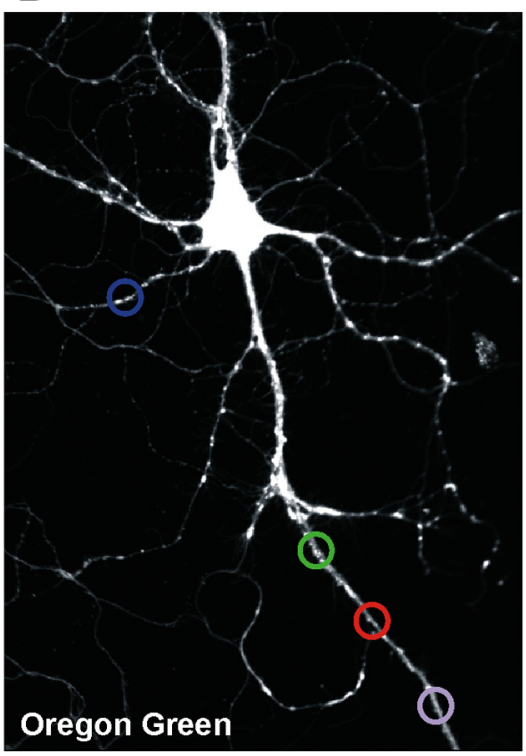

C

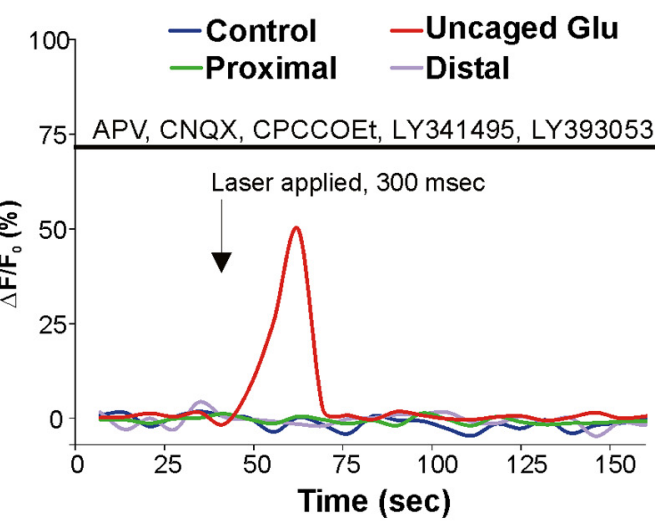

Figure 3. Regionally selective uncaging of glutamate in the presence of cell surface inhibitors activates intracellular mGluR5 in dendrites. $A$, Selective uncaging of MNI-glu in an ROI allows it to be taken up into the dendrite and subsequently the ER via EAAT3 transporters where it activates mGluR5. This leads to signaling via IP ${ }_{3}$ to release $\mathrm{Ca}^{2+}$ from the lumen of the ER. $B, C, M N I-g l u$ was uncaged on a neurite of a CA1 pyramidal cell at the red ROI in the presence of LY53 (20 $\mu \mathrm{M})$, the NMDA receptor blocker APV (100 $\mu \mathrm{M})$, the AMPA/kainate receptor blocker CNQX (20 $\mu \mathrm{M})$, the $\mathrm{mGluR1}$ blocker CPCCOEt $(20 \mu \mathrm{m})$, and the Group $2 \mathrm{mGluR}$ antagonist LY341495 (100 nM). Uncaged glutamate generated a $\mathrm{Ca}^{2+}$ rise at the red ROI, whereas no $\mathrm{Ca}^{2+}$ changes are seen proximal (green ROI), distal (lavender ROI), or in a different neurite in the same field (blue ROI) $(n=5)$.

littermates (Fig. 4C,D). Similarly, chemical LTD induced by CHPG was absent in mGluR5 knock-out animals (Fig. 4E). Surprisingly, DHPG-LTD, a common chemical LTD model (Palmer et al., 1997; Huber et al., 2001), was only partially suppressed in mGluR5-null mice.

Intracellular mGluR5 alone can mediate LTD, but not LTP In the striatum, activation of intracellular mGluR5 initiates a cascade of events underlying synaptic plasticity. Because numerous studies have suggested that mGluR5 is critically linked with changes in hippocampal LTP and LTD (Izumi et al., 2000), we tested whether intracellular mGluR5 also plays a role in these forms of synaptic plasticity. Consistent with previous work (Izumi et al., 2000), an HFS protocol applied to Schaffer collaterals in hippocampal slices induced a persistent $25-55 \%$ facilitation $1 \mathrm{~h}$ after stimulation (Fig. 5A). The nontransported antagonist LY53 blocked HFS-LTP, indicating that cell surface mGluR5 is critical in eliciting this form of LTP (Fig. 5A). MPEP, an antagonist that acts at both cell surface and intracellular mGluR5, also blocked HFS-LTP.

Synaptically induced mGluR-LTD can be evoked in hippocampal slices using LFS (Izumi et al., 2000) or by chemical agonists, such as Quis (Nicoletti et al., 2011), DHPG (Palmer et al., 1997; Huber et al., 2001), or CHPG (Palmer et al., 1997; Neyman and Manahan-Vaughan, 2008; Izumi and Zorumski, 2012). LFS normally induces $20-30 \%$ depression $1 \mathrm{~h}$ after stimulation. As observed by other investigators, MPEP application blocked LFS-LTD (Neyman and Manahan-Vaughan, 2008). However, in contrast to HFS-LTP, LY53 was unable to block LTD induction (Fig. 5B), indicating that intracellular mGluR5 was sufficient for this process. In terms of chemical LTD, application of LY53 was able to block DHPG-LTD (Fig. 5C), but not CHPGLTD (Fig. 5D) or Quis-LTD (Fig. 5E), indicating that activation of intracellular mGluR5 alone was sufficient to induce LTD and that cell surface mGluR5 was not required. As a control, MPEP was able to block both CHPG-LTD and Quis-LTD (Fig. 5D,E), indicating that these forms of LTD are mediated by mGluR5. Finally, incubation with the translation inhibitor anisomycin blocked CHPG-LTD (Fig. 5F), which agrees with previous studies that mGluR5-LTD is protein translation-dependent (Huber et al., 2000).

\section{Discussion}

Because mGluR5 is critically linked with fragile X syndrome, autism spectrum disorder, and many other disorders (Krueger and Bear, 2011), it is a key target for drug discovery. Surprisingly, no studies to date have focused on intracellular mGluR5 as a contributing factor to these disorders. The present findings show that, as in striatal neurons, intracellular mGluR5 is both present and functional in hippocampal neurons, where it can cause dendritic $\mathrm{Ca}^{2+}$ rises that differ in amplitude from cell surface receptor activation. Using genetic, physiological, and pharmacological techniques, these studies also show that intracellular mGluR5 can mediate protein-synthesis-dependent LTD, whereas cell surface mGluR5 is involved in both LTD and LTP. Thus, there may be large gaps in our understanding of mGluR5-LTD because of the contributions of intracellular mGluR5 signaling. Studies targeting drugs to cell surface versus intracellular receptors might lead to new therapeutic tools for fragile X syndrome/autism spectrum disorder, and levodopa-induced dyskinesias, gastroesophageal reflux disease, schizophrenia, and pain.

Although we would like to target mGluR5 to one membrane versus another, unequivocal targeting motifs have yet to be defined. Pharmacological isolation can be achieved, however, using a combination of impermeable, nontransported drugs together with permeable or transported ones. Drug permeability can be gauged using PubChem's lipophilicity values $(\log \mathrm{P})$ in which a LogP value $>2$ is considered to be readily membrane permeable (Lester et al., 2012). Only MPEP has a $\log P>2$ (3.3), which is in agreement with its ability to block all mGluR5 responses on and 

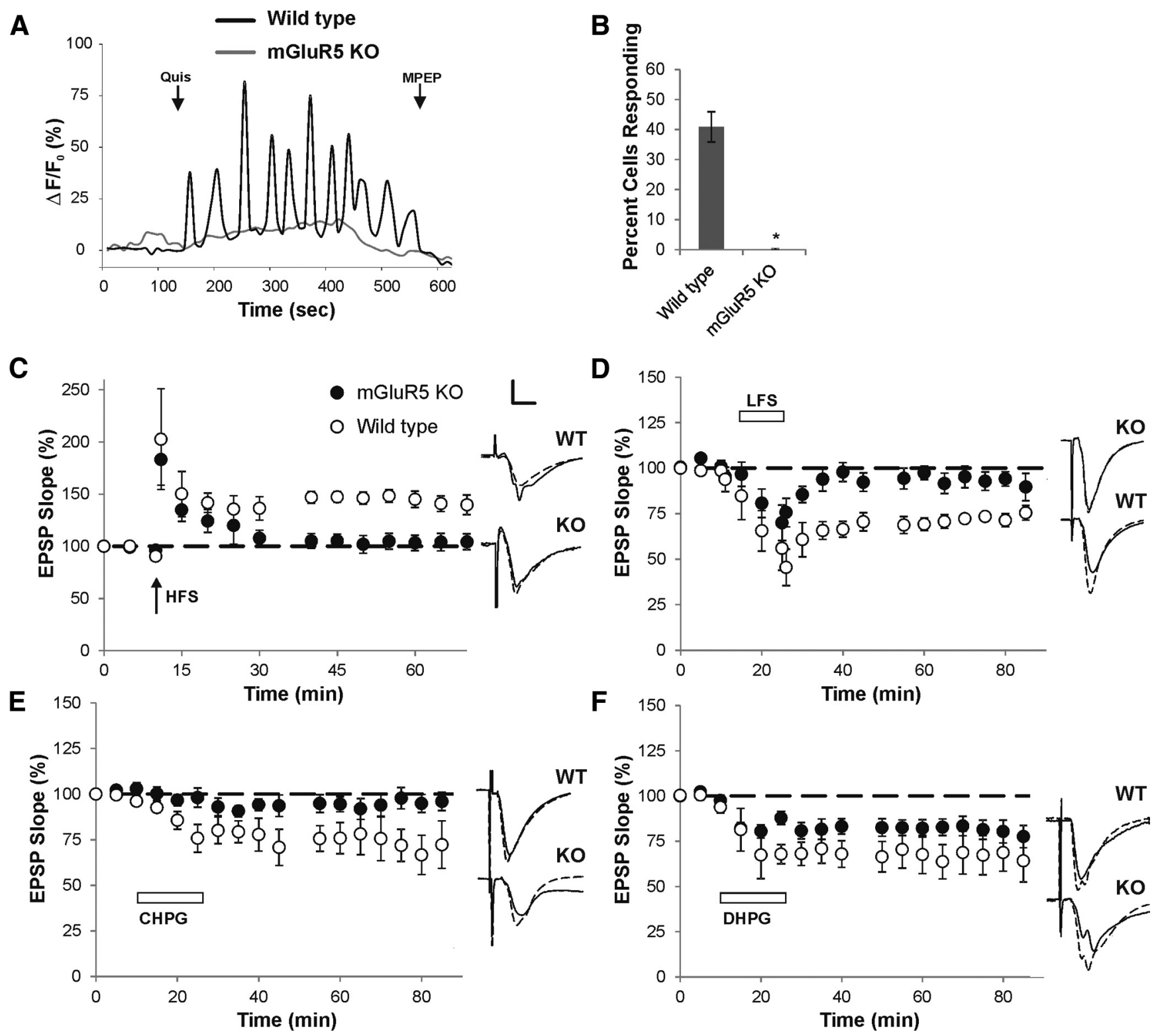

Figure 4. mGluR5 knock-out animals do not display mGluR5-dependent synaptic plasticity. $A$, Representative traces of $\mathrm{Ca}^{2+}$ responses shown as the fractional change in fluorescence relative to the basal level. CA1 neurons were treated with $20 \mu \mathrm{M}$ Quis and $10 \mu \mathrm{M}$ MPEP, as indicated by the arrows. Only wild-type mGluR5 neurons (black lines) displayed Quis-induced Ca ${ }^{2+}$ responses ( $n=$ 42 responding cells of 97 analyzed from 3 different animals), whereas neurons derived from mGluR5-null mice (gray line) did not respond to Quis ( $n=0$ responding cells of 72 analyzed from 3 different animals). $\boldsymbol{B}$, Compiled data from mGluR5 ${ }^{+/+}$(black bar) and mGluR5 ${ }^{-1-}$ neurons (gray bar). ${ }^{*} p<0.001$. C $\boldsymbol{F}$, Electrophysiology $(n=5$ wild-type, $n=9$ KO for each experiment): HFS-LTP (100 pulses at $100 \mathrm{~Hz}$; $\boldsymbol{C}$, LFS-LTD (900 pulses at $1 \mathrm{~Hz} ; \boldsymbol{D})$, and CHPG-LTD (E) are absent in mGluR5 K0 animals, whereas DHPG-LTD (F) is only partially diminished. $\boldsymbol{C}, \boldsymbol{D}$, Insets, Representative traces. Dashed lines indicate baseline; solid lines indicate traces in response to the indicated treatment after $60 \mathrm{~min}$. Calibration: $1 \mathrm{mV}, 5 \mathrm{~ms}$.

within the cell (e.g., Fig. 2). $\log P$ values for glutamate $(-2.7)$, DHPG (-2.4), CHPG (-1.4), LY53 (0.6), and Quis (-3.9) are consistent with the notion that they are membrane impermeable. Thus, for any of these compounds to get into the cell, there must be an active transport/exchange process. With radiolabeled analogs, such as exist for Quis and glutamate, it is easy to show that both are transported into neurons via a sodium or chloridedependent process (Jong et al., 2005, 2009; Kumar et al., 2008) (Fig. $1 \mathrm{H}, \mathrm{I}$ ). Without such a radiolabel, we have used competition assays to show that LY53 and DHPG do not compete with radiolabeled Quis or glutamate for cell entry, whereas CHPG does (Fig. $1 H)$. Additional functional data come from nuclei themselves. Because nuclei are composed of a double membrane and the mGluR5 ligand binding domain is within the nuclear lumen (O'Malley et al., 2003), only a permeable or transported drug can activate nuclear mGluR5. DHPG cannot induce nucleoplasmic $\mathrm{Ca}^{2+}$ changes in purified nuclei endogenously expressing mGluR5, whereas the subsequent application of Quis to the same organelle induces a robust response, one that is not blocked by LY53 (Jong et al., 2009). Collectively, these data and sources provide strong evidence that DHPG and LY53 only affect cell surface mGluR5, not intracellular receptors. In the hippocampus, mGluR5-induced changes in synaptic plasticity (mGluR5-LTD) have been primarily defined by DHPG (Palmer et al., 1997; Huber et al., 2001), which, as discussed above, only activates cell surface receptors (Jong et al., 2005). Thus, DHPG-induced LTD activates only a portion of mGluR5 responses. In addition, some of the DHPG-induced signals might represent off-target effects. For example, we recently reported that LTD induced by $100 \mu \mathrm{M}$ DHPG is not blocked by MPEP, indicating that DHPG actions 
A

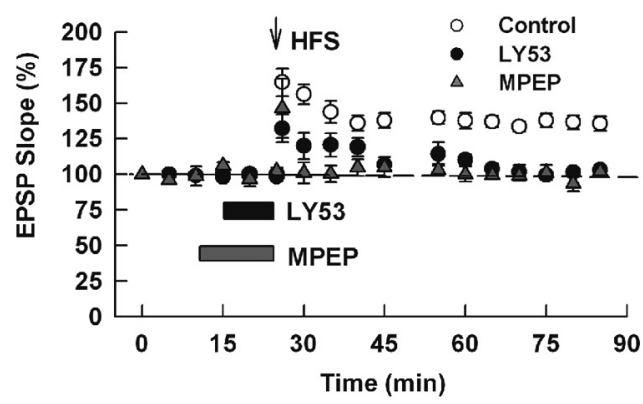

C

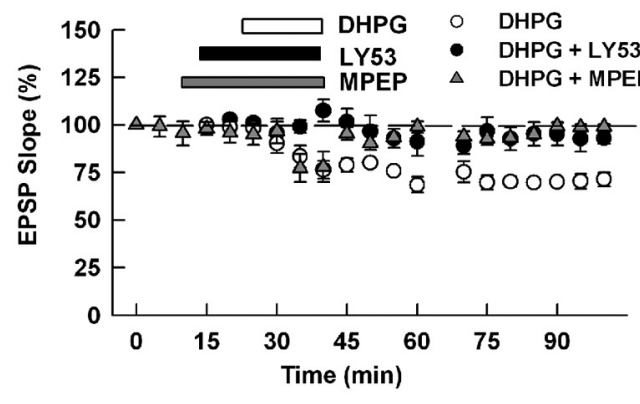

$\mathbf{E}$

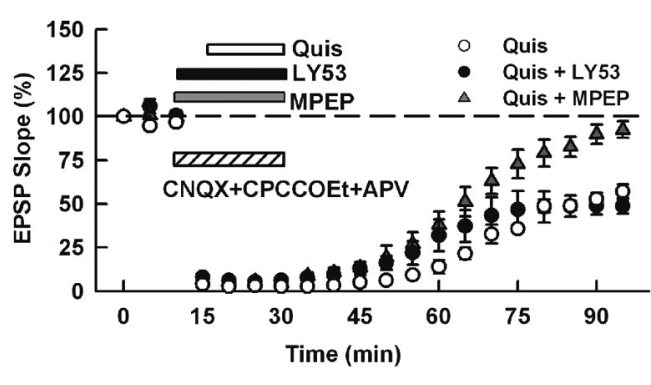

B
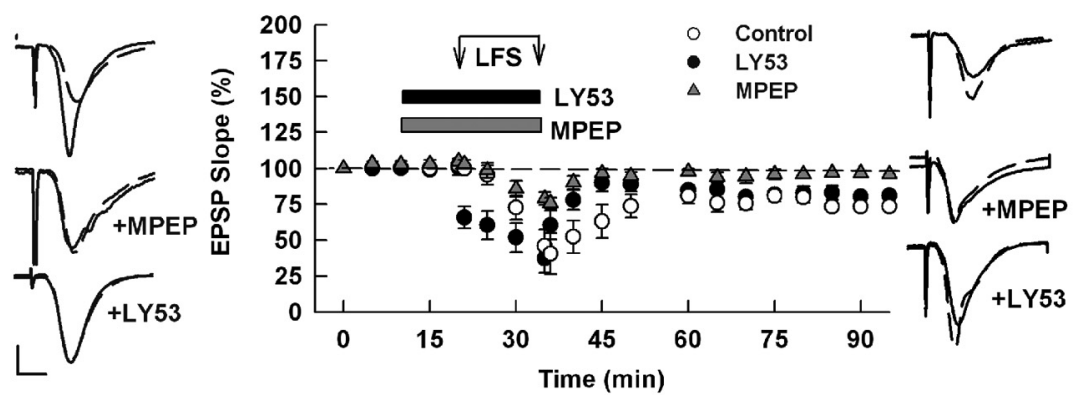

D
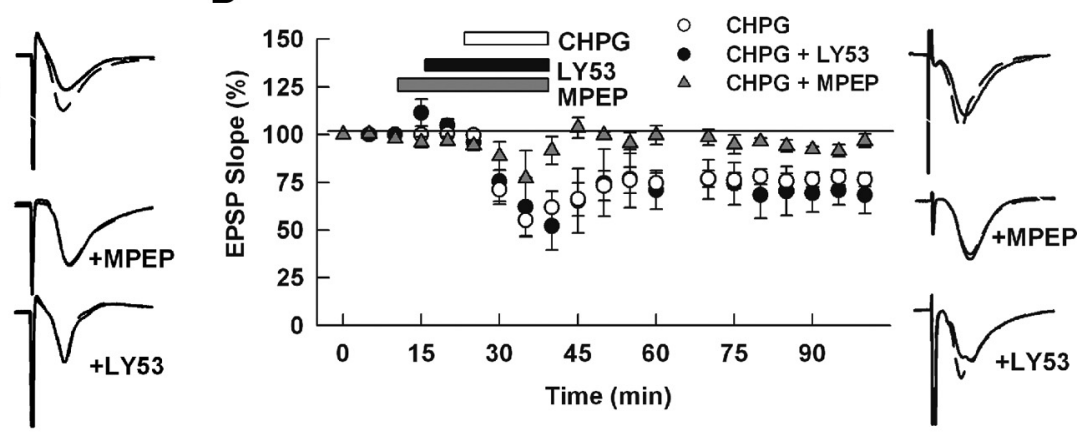

$\mathbf{F}$

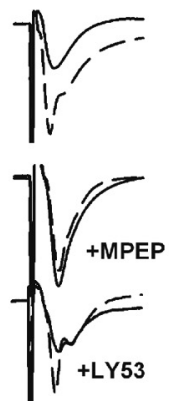

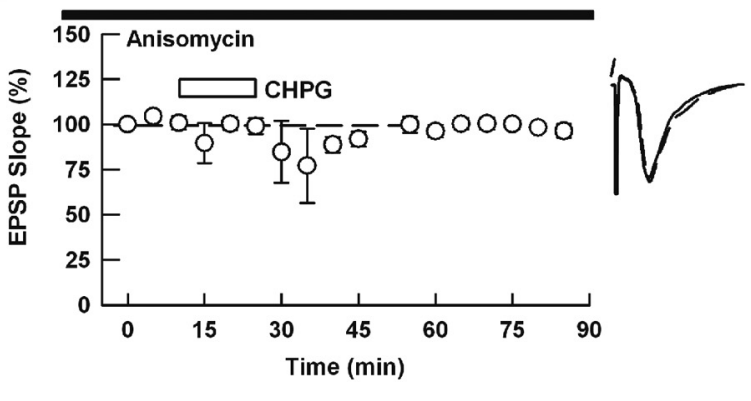

Figure 5. Activation of intracellular mGluR5 can mediate LTD, not LTP.A, HFS induced an enhancement of dendritic EPSPs that persisted for at least 60 min after stimulation. HFS-LTP was blocked by $10 \mu \mathrm{M} \mathrm{LY} 53$ or $10 \mu \mathrm{M}$ MPEP ( $n=6$ control, $n=7 \mathrm{LY} 53, n=5 \mathrm{MPEP})$. $\boldsymbol{B}$, LFS induced persistent synaptic depression that was not blocked by $10 \mu \mathrm{M}$ LY53, but was blocked by $10 \mu \mathrm{M}$ MPEP $(n=$ 5 for each condition). C, DHPG (10 $\mu \mathrm{m}$ ) induced LTD that was blocked by $10 \mu \mathrm{M} \mathrm{LY53}$ or by $10 \mu \mathrm{M}$ MPEP ( $n=5$ for each condition). D, CHPG ( $250 \mu \mathrm{M}$ ) also induced LTD that was not blocked by 10 $\mu \mathrm{MLY} 53$ but was blocked by $10 \mu \mathrm{MMPEP}(n=10$ control, $n=7 \mathrm{LY} 53, n=5 \mathrm{MPEP})$. E, Application of $10 \mu \mathrm{M}$ Quis (white bar) for $15 \mathrm{~min}$ (in the presence of inhibitors to isolate $\mathrm{mGluR5}$ activation: $10 \mu \mathrm{M}$ CNQX, $20 \mu \mathrm{M}$ CPCCOEt, $100 \mu \mathrm{m}$ APV; striped bar) induced chemical LTD (open circles). The depression was attenuated by $10 \mu \mathrm{m}$ MPEP (gray bar; triangles), but not by $10 \mu \mathrm{m}$ LY53 (black bar; closed circles) ( $n=5$ for each experiment). $\boldsymbol{F}$, Translation inhibitor anisomycin $(20 \mu \mathrm{M})$ blocks CHPG-LTD $(n=5)$. Insets, Representative traces. Dashed lines indicate baseline; solid lines indicate traces in response to the indicated treatment after $60 \mathrm{~min}$. Calibration: $1 \mathrm{mV}, 5 \mathrm{~ms}$.

are not completely specific (Izumi and Zorumski, 2012). Although only $10 \mu \mathrm{M}$ DHPG was used here to induce chemical LTD, even this low concentration induced partial LTD in mGluR5 KO mice (Fig. 4F). These results confirm DHPG offtarget effects and possible compensatory changes in expression of other receptors in mGluR5 KO mice compared with wild-type mice or rats. In contrast, HFS, LFS, and CHPG-induced responses were completely absent in mGluR5 KO slices. In wildtype slices, HFS or LFS activates intracellular mGluR5 via synaptically released glutamate uptake, presumably via EAAT3 (Jong et al., 2009) (Fig. 1I). Our findings that LY53 completely blocked HFS-induced LTP and DHPG-induced LTD, but not LFS or CHPG-induced LTD, led us to conclude that activation of intracellular mGluR5 is sufficient to produce LTD but not LTP. One caveat to the latter, however, is that because a selective intracellular mGluR5 inhibitor is not currently available (MPEP inhibits both surface and intracellular mGluR5s), the possible involvement of intracellular mGluR5 in LTP cannot be excluded.
mGluR-LTD has been shown to be dependent on protein translation, but not mRNA transcription (Huber et al., 2000). In accordance with this, CHPG-LTD in our experiments was similarly translation-dependent, as it was blocked by anisomycin (Fig. $5 F)$. Because intracellular mGluR5 activation alone can drive CHPG-LTD (Fig. 5D), this suggests that intracellular mGluR5, like its cell surface counterpart, also induces LTD via a protein translation-dependent mechanism.

mGluR5 oscillatory $\mathrm{Ca}^{2+}$ responses are thought to result from rapid, cyclical phosphorylation via PKC, which uncouples the receptor from $\mathrm{G}_{\mathrm{q} / 11} / \mathrm{PLC}$ activation (Kawabata et al., 1996; Kim et al., 2005). In addition toPKC, receptor density and levels of agonist stimulation can affect $\mathrm{Ca}^{2+}$ responses (Kawabata et al., 1996; Kim et al., 2005). Thus, potential regional differences in receptor density might explain somal oscillations versus sustained dendritic $\mathrm{Ca}^{2+}$ patterns (Fig. 2). An alternative explanation might be a difference in the types of proteins that are complexed with cell surface receptors in the soma or dendrites and/or intracellular 
receptors in any location. The $\mathrm{C}$ terminus of mGluR5 interacts with many scaffolding proteins, including homers, which link mGluR5 on the plasma membrane to surface and intracellular $\mathrm{Ca}^{2+}$ channels, NMDA receptors, as well as other binding proteins, such as CAL, Norbin, calmodulin, SIAH, Tamalin, NECAB2, CAIN, PKC, GRK2, CaMKII, and various cytoskeletal components (Enz, 2012; Fagni, 2012). Therefore, unique functional signaling entities might be found at cell surfaces or intracellular membranes in somal compartments and similarly at dendritic surface or intracellular membranes. Other possible explanations for the differences in somal versus dendritic $\mathrm{Ca}^{2+}$ signaling characteristics would include the embryonic age of the cultures versus the postnatal slice preparations and the dissociated nature of in vitro neurons versus the intact connections in an ex vivo slice preparation. Determining which of these mechanisms underlies this phenomenon will require further experimentation.

Given that striatal cultures consist mainly of inhibitory GABAergic medium spiny neurons whereas CA1-enriched hippocampal cultures are primarily excitatory glutamatergic pyramidal cells, these studies extend the repertoire of intracellular mGluR5 into a different cell type. As such, intracellular mGluR5 responses might exhibit different downstream sequelae and use unique signaling pathways. One possible point of convergence, however, might lie in the intracellular mGluR5-mediated activation of synaptic plasticity genes, such as activity-regulated cytoskeletal-associated protein (Arc/Arg3.1) in the striatal culture system (Kumar et al., 2012). Interestingly, Arc upregulation has been associated with both LTD and LTP induction in the hippocampus (Bramham et al., 2008). Therefore, determining whether cell surface, intracellular, or both pools of mGluR5 underlies this response is important.

Whereas isolated nuclear preparations comprise a suitable means by which to study receptors on the nuclear membrane, other intracellular membranes are more difficult to isolate while maintaining functionality. Although mGluR5 located on the ER has not been physically isolated, uncaging glutamate in the presence of LY53 (Fig. 3) clearly demonstrates that mGluR5 localized to this organelle is not just undergoing maturation and processing but is also capable of sending signals. Because the ER extends into dendritic spines (Wagner et al., 2011) and rapid translation of synaptic proteins involved in LTD is thought to occur locally at the synapse, it is conceivable that mGluR5 located on dendritic spine ER is responsible for the LTD effects shown in Figure 5.

mGluR5 is highly regulated by various activity-dependent processes, notably phosphorylation at multiple sites via multiple kinases largely resulting in receptor internalization (Mao et al., 2008). Although internalization is often thought of as a way to terminate receptor signaling, the discovery that endocytosed GPCRs can trigger a whole new battery of intracellular messengers has catalyzed the search for (1) "biased ligands" that can shift a receptor's response from one signaling pathway to another and (2) the underlying mechanisms associated with the novel signaling pathways (Reiter et al., 2012). Interestingly, mGluR5 's close homolog, mGluR1, has been reported to display ligand bias (Emery et al., 2012; Kammermeier, 2012). Specifically, succinic and glutaric acid appeared to bias mGluR1 toward $\beta$-arrestinmediated signaling, whereas both DHPG and Quis biased mGluR1 toward G-protein signaling in heterologous cells (Emery et al., 2012). These biased ligand effects were not observed for mGluR5 (Emery et al., 2010). Furthermore, mutations in the $\beta$-arrestin binding site on the $\mathrm{C}$ terminus of mGluR5 (Sorensen and Conn, 2003) do not affect the patterns of $\mathrm{Ca}^{2+}$ signaling (unpublished data). Thus, results in both striatal neurons and hippocampal CA1 cells reflect location bias as opposed to ligand bias.

In conclusion, the findings presented here underscore the idea that mGluR5 is functional on intracellular membranes as well as on the cell surface. Although past experiments have examined mGluR5 in heterologous cell types and striatal cultures, here we show intracellular mGluR5 is functional in the hippocampus and directly involved in synaptic plasticity. Further studies regarding the signaling properties of intracellular mGluR5 could be beneficial in the development of targeted therapeutics to correct the synaptic defects present in mGluR5-related disorders.

\section{References}

Bkaily G, Avedanian L, Al-Khoury J, Ahmarani L, Perreault C, Jacques D (2012) Receptors and ionic transporters in nuclear membranes: new targets for therapeutical pharmacological interventions. Can J Physiol Pharmacol 90:953-965. CrossRef Medline

Blandini F, Armentero MT (2012) New pharmacological avenues for the treatment of L-DOPA-induced dyskinesias in Parkinson's disease: targeting glutamate and adenosine receptors. Expert Opin Investig Drugs 21: 153-168. CrossRef Medline

Bramham CR, Worley PF, Moore MJ, Guzowski JF (2008) The immediate early gene arc/arg3.1: regulation, mechanisms, and function. J Neurosci 28:11760-11767. CrossRef Medline

Catania MV, D'Antoni S, Bonaccorso CM, Aronica E, Bear MF, Nicoletti F (2007) Group I metabotropic glutamate receptors: a role in neurodevelopmental disorders? Mol Neurobiol 35:298-307. CrossRef Medline

Cleva RM, Olive MF (2011) Positive allosteric modulators of type 5 metabotropic glutamate receptors (mGluR5) and their therapeutic potential for the treatment of CNS disorders. Molecules 16:2097-2106. CrossRef Medline

Denis C, Saulière A, Galandrin S, Sénard JM, Galés C (2012) Probing heterotrimeric G-proteinactivation: applications to biased ligands. Curr Pharm Des 18:128-144. CrossRef Medline

Emery AC, Pshenichkin S, Takoudjou GR, Grajkowska E, Wolfe BB, Wroblewski JT (2010) The protective signaling of metabotropic glutamate receptor 1 Is mediated by sustained, beta-arrestin-1-dependent ERK phosphorylation. J Biol Chem 285:26041-26048. CrossRef Medline

Emery AC, DiRaddo JO, Miller E, Hathaway HA, Pshenichkin S, Takoudjou GR, Grajkowska E, Yasuda RP, Wolfe BB, Wroblewski JT (2012) Ligand bias at metabotropic glutamate la receptors: molecular determinants that distinguish $\beta$-arrestin-mediated from $G$ protein-mediated signaling. Mol Pharmacol 82:291-301. CrossRef Medline

Enz R (2012) Structure of metabotropic glutamate receptor C-terminal domains in contact with interacting proteins. Front Mol Neurosci 5:52. CrossRef Medline

Fagni L (2012) Diversity of metabotropic glutamate receptor-interacting proteins and pathophysiological functions. Adv Exp Med Biol. 970:63-79. CrossRef Medline

Gray LJ, Hannan AJ, Zhang X (2012) Metabotropic glutamate receptors as targets for novel antipsychotic treatments. Curr Pharm Biotechnol 13: 1522-1534. CrossRef Medline

Hanson JE, Smith Y (1999) Group I metabotropic glutamate receptors at GABAergic synpases in monkeys. J Neurosci 19:6488-6496. Medline

Hewavitharana T, Wedegaertner PB (2012) Non-canonical signaling and localizations of heterotrimeric $\mathrm{G}$ proteins. Cell Signal 24:25-34. CrossRef Medline

Huber KM, Kayser MS, Bear MF (2000) Role for rapid dendritic protein synthesis in hippocampal mGluR-dependent LTD. Science 288:12541257. CrossRef Medline

Huber KM, Roder JC, Bear MF (2001) Chemical induction of mGluR5- and protein synthesis-dependent long-term depression in hippocampal area CA1. J Neurophysiol 86:321-325. Medline

Hubert GW, Paquet M, Smith Y (2001) Differential subcellular localization of mGluR1a and mGluR5 in the rat and monkey Substantia nigra. J Neurosci 6:1838-1847. Medline

Izumi Y, Zorumski CF (2012) NMDA receptors, mGluR5, and endocannabinoids are involved in a cascade leading to hippocampal long-term depression. Neuropsychopharmacology 37:609-617. CrossRef Medline

Izumi Y, Zarrin AR, Zorumski CF (2000) Arachidonic acid rescues hip- 
pocampal long-term potentiation blocked by group I metabotropic glutamate receptor antagonists. Neuroscience 100:485-491. CrossRef Medline

Jong YJ, Kumar V, Kingston AE, Romano C, O’Malley KL (2005) Functional metabotropic glutamate receptors on nuclei from brain and primary cultured striatal neurons: role of transporters in delivering ligand. J Biol Chem 280:30469-30480. CrossRef Medline

Jong YJ, Schwetye KE, O'Malley KL (2007) Nuclear localization of functional metabotropic glutamate receptor mGlu1 in HEK293 cells and cortical neurons: role in nuclear calcium mobilization and development. J Neurochem 101:458-469. CrossRef Medline

Jong YJ, Kumar V, O’Malley KL (2009) Intracellular metabotropic glutamate receptor 5 (mGluR5) activates signaling cascades distinct from cell surface counterparts. J Biol Chem 284:35827-35838. CrossRef Medline

Kammermeier PJ (2012) The orthosteric agonist 2-chloro-5-hydroxyphenylglycine activates mGluR5 and mGluR1 with similar efficacy and potency. BMC Pharmacol 12:6. CrossRef Medline

Kawabata S, Tsutsumi R, Kohara A, Yamaguchi T, Nakanishi S, Okada M (1996) Control of calcium oscillations by phosphorylation of metabotropic glutamate receptors. Nature 383:89-92. CrossRef Medline

Kim CH, Braud S, Isaac JT, Roche KW (2005) Protein kinase C phosphorylation of the metabotropic glutamate receptor mGluR5 on Serine 839 regulates $\mathrm{Ca}^{2+}$ oscillations. J Biol Chem 280:25409-25415. CrossRef Medline

Krueger DD, Bear MF (2011) Toward fulfilling the promise of molecular medicine in fragile X syndrome. Annu Rev Med 62:411-429. CrossRef Medline

Kumar V, Jong YJ, O'Malley KL (2008) Activated nuclear metabotropic glutamate receptor mGlu5 couples to nuclear $\mathrm{Gq} / 11$ proteins to generate inositol 1,4,5-trisphosphate-mediated nuclear $\mathrm{Ca}^{2+}$ release. J Biol Chem 283:14072-14083. CrossRef Medline

Kumar V, Fahey PG, Jong YJ, Ramanan N, O’Malley KL (2012) Activation of intracellular metabotropic glutamate receptor 5 in striatal neurons leads to up-regulation of genes associated with sustained synaptic transmission including Arc/Arg3.1 protein. J Biol Chem 287:5412-5425. CrossRef Medline

Kuwajima M, Hall RA, Aiba A, Smith Y (2004) Subcellular and subsynaptic localization of group I metabotropic glutamate receptors in the moneky subthalamic nucleus. J Comp Neurol 474:589-602. CrossRef Medline

Lester HA, Miwa JM, Srinivasan R (2012) Psychiatric drugs bind to classical targets within early exocytotic pathways: therapeutic effects. Biol Psychiatry 72:907-915. CrossRef Medline

López-Bendito G, Shigemoto R, Fairén A, Luján R (2002) Differential distribution of group I metabotropic glutamate receptors during rat cortical development. Cereb Cortex 12:625-638. CrossRef Medline

Lujan R. Nusser Z. Roberts JD, Shigemoto R, Somogyi P (1996) Prerisynaptic location of metabotropic glutamate receptors mGluR1 and mGluR5 on dendrites and dendritic spines in the rat hippocampus. Eur J Neurosci 7:1488-1500. Medline

Mao LM, Liu XY, Zhang GC, Chu XP, Fibuch EE, Wang LS, Liu Z, Wang JQ (2008) Phosphorylation of group I metabotropic glutamate receptors (mGluR1/5) in vitro and in vivo. Neuropharmacology 55:403-408. CrossRef Medline

Mitrano DA, Smith Y (2007) Comparative analysis of the subcellular and subsynaptic localization of mGluR1a and mGluR5 metabotropic glutamate receptors in the shell and core of the nucleus accumbens in rat and monkey. J Comp Neurol 500:788-806. CrossRef Medline

Mitrano DA, Arnold C, Smith Y (2008) Subcellular and subsynaptic localization of group I metabotropic glutamate receptors in the nucleus accumbens of cocaine-treated rats. Neuroscience 154:653-666. CrossRef Medline

Mitrano DA, Pare JF, Smith Y (2010) Ultrastructural relationships between cortical, thalamic, and amygdala glutamatergic inputs and group I metabotropic glutamate recetpors in the rat accumbens. J Comp Neurol 518:1315-1329. CrossRef Medline

Neyman S, Manahan-Vaughan D (2008) Metabotropic glutamate receptor 1 (mGluR1) and 5 (mGluR5) regulate late phases of LTP and LTD in the hippocampal CA1 region in vitro. Eur J Neurosci 27:1345-1352. CrossRef Medline

Nicoletti F, Bockaert J, Collingridge GL, Conn PJ, Ferraguti F, Schoepp DD, Wroblewski JT, Pin JP (2011) Metabotropic glutamate receptors: from the workbench to the bedside. Neuropharmacology 60:1017-1041. CrossRef Medline

O’Malley KL, Jong YJ, Gonchar Y, Burkhalter A, Romano C (2003) Activation of metabotropic glutamate receptor mGlu5 on nuclear membranes mediates intranuclear $\mathrm{Ca}^{2+}$ changes in heterologous cell types and neurons. J Biol Chem 278:28210-28219. CrossRef Medline

Palmer MJ, Irving AJ, Seabrook GR, Jane DE, Collingridge GL (1997) The group I mGlu receptor agonist DHPG induces a novel form of LTD in the CA1 region of the hippocampus. Neuropharmacology 36:1517-1532. CrossRef Medline

Reiter E, Ahn S, Shukla AK, Lefkowitz RJ (2012) Molecular mechanism of $\beta$-arrestin-biased agonism at seven-transmembrane receptors. Annu Rev Pharmacol Toxicol. 52:179-197. CrossRef Medline

Romano C, Yang WL, O’Malley KL (1996) Metabotropic glutamate receptor 5 is a disulfide-linked dimer. J Biol Chem 271:28612-28616. CrossRef Medline

Sorensen SD, Conn PJ (2003) G protein-coupled receptor kinases regulate metabotropic glutamate receptor 5 function and expression. Neuropharmacology 44:699-706. CrossRef Medline

Wagner W, Brenowitz SD, Hammer JA 3rd (2011) Myosin-Va transports the endoplasmic reticulum into the dendritic spines of Purkinje neurons. Nat Cell Biol 13:40-48. CrossRef Medline 